\title{
IMPLEMENTATION OF NATURAL FILLERS IN POLYETHYLENE AND THE RESULTING MECHANICAL PROPERTIES
}

\author{
UPORABA NARAVNIH POLNIL V POLIETILENU IN NJIHOVE \\ MEHANSKE LASTNOSTI
}

\author{
Adam Dockal, Martin Ovsik*, Petr Fluxa, Michal Stanek, Vojtech Senkerik \\ Tomas Bata University in Zlín, Vavrečkova 275, 76001 Zlín, Czech Republic \\ Prejem rokopisa - received: 2019-07-15; sprejem za objavo - accepted for publication: 2019-12-23
}

doi:10.17222/mit.2019.154

\begin{abstract}
In recent years, materials with natural fillers have begun to be used for manufacturing window frames and various linings. These compounds can replace natural materials such as wood and stone. The main reasons to use these fillers are price (which is lower than that of a polymer) and rigidity. The resulting product is strong, hard, light, possesses a long-term resistance to wind abrasion and takes on the appearance of wood and stone. The type of filler has a significant effect on the final properties of the material. In the past, however, insufficient attention was paid to the effect of natural fillers on the injection-molded product's mechanical properties. First, the test samples were measured by depth sensing indentation (DSI), which is a contemporary instrumented hardness test used to determine the micro-mechanical properties. A Micro Combi Tester made by the Anton Paar company was used for these tests. Then, the measurements were evaluated by the Oliver and Pharr method. The goal of this study was to prepare a low-density polyethylene (LDPE) filled with varying natural fillers, e.g., finely ground wood, coarsely ground wood and slate) and its subsequent granulation. The implementation of these fillers led to an increase of the mechanical properties, e.g., indentation hardness and modulus, by up to $100 \%$ in comparison with the virgin material. The goal of this study was to evaluate the effect of natural fillers, such as wood and slate, on the mechanical properties of the tested materials. Keywords: polyethylene, natural fillers, mechanical properties, indentation hardness
\end{abstract}

V zadnjih letih so se materiali z naravnimi polnili začeli uporabljati za okvire oken in različnih cevi. Te spojine oz. kompozitni materiali lahko zamenjajo naravne materiale, kot sta na primer les in kamen. Glavni razlog za uporabo teh polnil je cena, ki znižuje ceno čistega polimera in povečuje njegovo togost. Kompozitni izdelek (polimer z dodatkom polnila) je močan, trd, svetel, gladek, trajno odporen proti abraziji in ima lahko izgled lesa ali kamna. Izbrana vrsta polnila ima pomemben vpliv na končne lastnosti kompozitnega materiala. V preteklosti so proizvajalci teh vrst materialov posvečali premalo pozornosti vplivu naravnih polnil na mehanske lastnosti injekcijsko brizganih izdelkov. Avtorji članka so najprej izmerili nanotrdoto vzorcev, ki zadovoljivo okarakterizira njihove mikromehanske lastnosti. Za meritve so uporabili Micro Combi Tester, izdelan v podjetju Anton Paar. Nato so meritve ovrednotili z Oliver in Pharr metodo. Cilj študije je bil pripraviti polietilen z nizko gostoto (LDPE), polnjen $\mathrm{z}$ različnimi naravnimi polnili in sicer $\mathrm{z}$ grobo drobljenim lesom ali skrilavcem, ki so ju naknadno granulirali. Uporaba teh polnil je povečala mehanske lastnosti kompozitnega materiala (indentacijsko nanotrdoto in modul) za do $100 \% \mathrm{v}$ primerjavi s čistim izvornim materialom. Cilj študije je bil ovrednotiti vpliv dodatka različne vsebnosti in granulacije naravnih polnil, kot sta les in skril, na mehanske lastnosti preiskovanih materialov.

Ključne besede: polietilen, naravna polnila, mehanske lastnosti, nanotrdota

\section{INTRODUCTION}

Wood-Plastic Composite (WPC) is a commonly used material, which was created in order to look like and potentially replace wood massive. This composite could have a greater resistance to outdoor conditions, while having low maintenance. WPC contains two main components, the polymer as a matrix and the wood as a filler. WPC is not limited only to wood fillings, but can also employ various other natural materials, such as linen, cannabis or the remains of agricultural plants. Wood as filler can be used in different forms, for example, wood flour, finely grinded wood or wood fibres. The content of the filler in the WPC is usually in the range 50-70\%. Wood fillers are often used for their rigidity and low cost, which is lower than the price of a polymer. The resulting product manufactured from poly-

*Corresponding author's e-mail

ovsik@utb.cz (Martin Ovsik) mer and wood is a strong, hard and light material with a surface layer resembling wood. The area in which WPC can be utilized has been slowly expanding in recent years; its greatest application can be divided into two groups. In construction, WPC is used for exterior and lately some interior materials. The second area of interest is the automotive industry, in which the WPC is mostly used for the interior parts.

\section{EXPERIMENTAL PART}

The low-density polyethylene (LDPE) called BRALEN VA 20-60 was chosen as the matrix material. As the filler, two types of beech wood with diverse particle sizes and various volumes were used. The first type was finely grounded beech wood with a particle length up to $0.5 \mathrm{~mm}$, as can been seen in Figure 1a, while the latter type was coarsely ground beech wood with a particle length up to $3 \mathrm{~mm}$ (Figure 1b). For the second filler, 


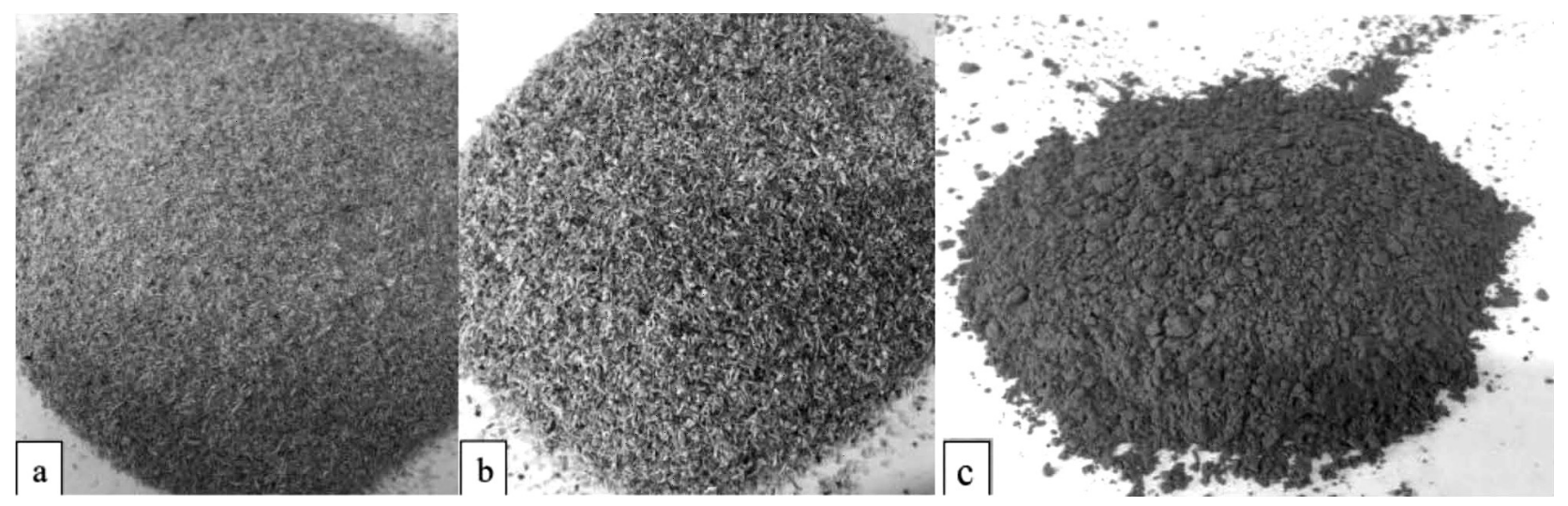

Figure 1: Natural fillers

slate was chosen, as depicted in Figure 1c. The volume of the individual fillers was $50 \%$.

The material was prepared in the laboratory on a planetary extruder line. The top part of the line consisted of feeder, lateral spindle and planetary section containing 12 spindles. To manufacture the test samples a conventional Arburg $170 \mathrm{U}$ Allrounder injection machine was used.

Micro-indentation properties were measured by means of Micro-Hardness Tester MHT3 made by Anton

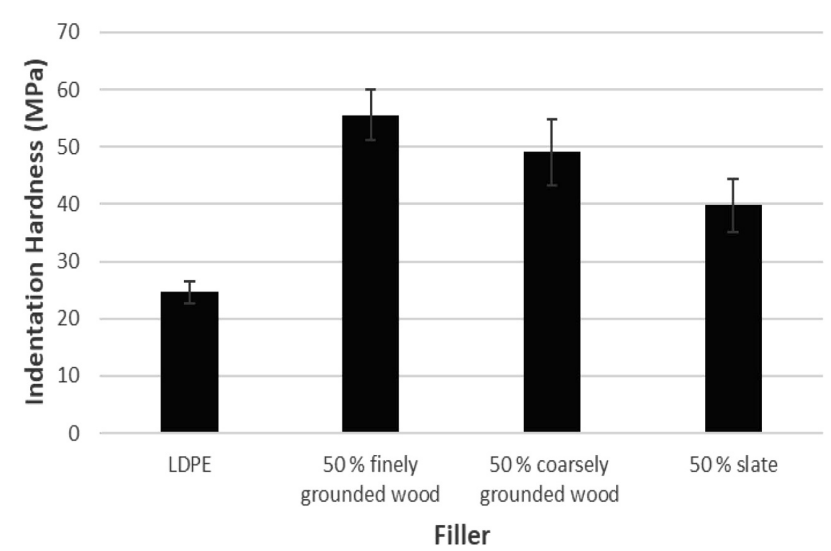

Figure 2: Indentation hardness

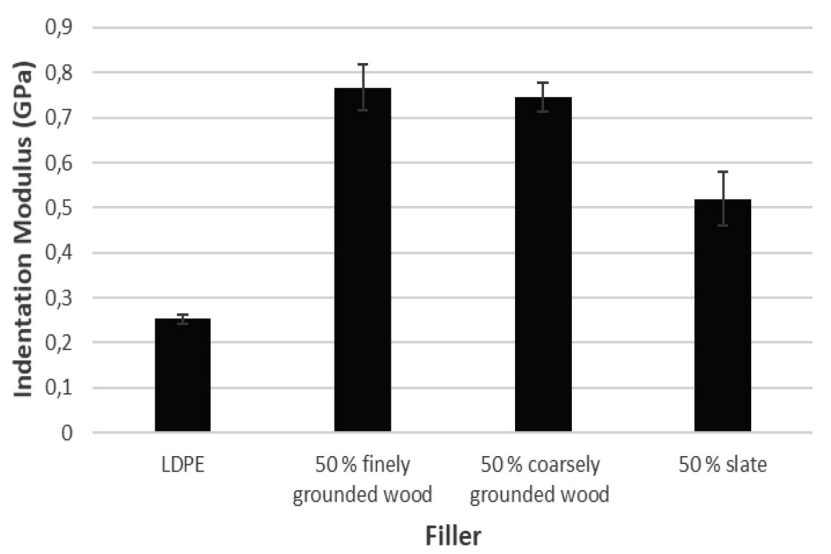

Figure 3: Indentation modulus
Paar (Graz, Austria), according to the CSN EN ISO 14577 standard. In the present study, the maximum load used was $0.5 \mathrm{~N}$ and the loading rate (and unloading rate) was $1 \mathrm{~N} / \mathrm{min}$. The holding time was $90 \mathrm{~s}$. The measured data were evaluated using the Oliver and Pharr method.

\section{RESULTS}

To measure the indentation hardness and indentation modulus of the LDPE filled with natural fillers, e.g., finely ground wood, coarsely ground wood and slate, a DSI method was implemented.

\section{DISCUSSION}

As is evident from Figure 2, with an increasing filler volume, the observed mechanical properties increased. The best indentation hardness (56 MPa) for a $50 \%$ filler concentration was found in polymer filled with finely ground wood. The indentation hardness rose by $125 \%$ in comparison to the virgin material. The material filled with coarsely grinded wood displayed an indentation hardness value of $49 \mathrm{MPa}$, which is $99 \%$ higher than that of the virgin material. The material containing $50 \%$ slate was measured to have an indentation hardness of 40 $\mathrm{MPa}$, which is $62 \%$ higher in comparison with the unaltered material.

As can be seen in Figure 3, natural fillers affect the indentation modulus of the LDPE. The values that were used for the comparison represent the indentation modulus of the unaltered LDPE, for which the value was $0.25 \mathrm{GPa}$. The measurements show that the best indentation modulus for the finely grinded wood $(0.77 \mathrm{GPa})$ was found in the compound with a $50 \%$ filler volume. Furthermore, LDPE containing $50 \%$ of coarsely grinded wood displayed an indentation modulus of $0.75 \mathrm{GPa}$. Ultimately, the lowest indentation modulus (0.52 GPa) was measured in LDPE containing $50 \%$ of slate. The first compound containing $50 \%$ of finely grinded wood displayed an impressive $201 \%$ increase in the inden- 
tation modulus in comparison with the unaltered material.

\section{CONCLUSIONS}

The best improvements of indentation hardness and indentation modulus were seen in the compound of LDPE with $50 \%$ of finely grinded beech sawdust. The indentation properties rose by $125 \%$ in comparison with the virgin material. A similar trend was observed for the compound containing roughly grinded beech sawdust. The test samples manufactured from LDPE with $50 \%$ of slate displayed a $62 \%$ increase of the indentation properties in comparison with the unaltered material. WPC material is often used to manufacture tiling materials or window frames and so it is quite important to be familiar with its properties. The type of filler that is used has a substantial influence on the WPC's properties. In the past, there was not a lot of attention paid to the mechanical properties of these fillers.

\section{Acknowledgment}

This work was supported by the European Regional Development Fund under the project CEBIA-Tech Instrumentation No. CZ.1.05/2.1.00/19.0376 and by the Ministry of Education, Youth and Sports of the Czech Republic within the National Sustainability Program project no. LO1303 (MSMT-7778/2014). Moreover, it was supported by the Internal Grant Agency of TBU in Zlin: no. IGA/FT/2020/003.

\section{REFERENCES}

${ }^{1}$ W. C. Oliver, G. M. Pharr, Measurement of hardness and elastic modulus by instrumented indentation, Journal of Materials Research, 19 (2004), 1564 - 1583

${ }^{2}$ R. M. Rowell. Handbook of wood chemistry and wood composites. 1. Boca Raton, CRC Press, 2005

${ }^{3}$ C. Vasile, G. E. Zaikov, New trends in natural and synthetic polymer science, New York: Nova Science Publishers 2006 